\title{
Impact on the quality of life of dermatological patients in southern Brazil ${ }^{*}$
}

\author{
Impacto na qualidade de vida de pacientes dermatológicos no sul do Brasil
}

\author{
Caroline dos Santos Tejada ${ }^{1}$ \\ Hiram Larangeira de Almeida $\mathrm{Jr}^{3}$ \\ Victor Felipe dos Santos Tejada
}

\author{
Raúl Andrés Mendoza-Sassi ${ }^{2}$ \\ Paulo Neves Figueiredo ${ }^{4}$
}

\begin{abstract}
BACKGROUNDS: Skin diseases are extremely frequent and may affect quality of life; therefore, it is important to assess it and identify which factors are associated with it.

OBJECTIVES: To assess quality of life and its associated factors in dermatological patients.

Methods: A cross-sectional study involving a sample of 548 patients seen at the Dermatology Outpatient Clinic of Sistema Único de Saúde (the Brazilian National Public Health System), University Hospital, Federal University of Rio Grande do Sul (RS). Information related to socio-demographic data, medical consultation and quality of life was collected by means of the Dermatology Life Quality Index.

RESULTS: A median of 7 and a mean of $7.7(S D=5.0)$ were obtained with the Dermatology Life Quality Index. The skin diseases with higher scores on the Dermatology Life Quality Index were psoriasis (median $=15.5$ ), vitiligo (median $=13)$, atopic dermatitis $($ median $=12)$ and acne $($ median $=10)$. With respect to factors associated with quality of life, it was found that younger, single patients with a low income, one skin disease and longer disease duration presented poorer quality of life.

Conclusion: The assessment of the impact of dermatoses on patients' quality of life is important for clinical management. It is essential to detect patients at higher risk of experiencing worse quality of life in order to treat them in a more integrated way.
\end{abstract}

Keywords: Dermatology; Epidemiology; Quality of life

Resumo: Fundamentos: As doenças de pele são extremamente freqüentes e os pacientes podem ter a qualidade de vida afetada. Assim é importante medi-la, bem como verificar quais os fatores que podem estar associados. OвJEтIVOs: Verificar a qualidade de vida em pacientes dermatológicos e os fatores associados.

MÉTODOS: Estudo tranversal com uma amostra de 548 pacientes atendidos no ambulatório de dermatologia do Sistema Único de Saúde do Hospital Universitário da Universidade Federal do Rio Grande. As informações foram coletadas em um questionário pré-codificado e referiam-se à dados sócio-demográficos, da consulta e qualidade de vida.

Resultados: O escore total do Dermatology Life Quality Index foi uma mediana de 7 e uma média de 7,7 $(\mathrm{DP}=5,0)$. As dermatoses com escore maior no Dermatology Life Quality Index foram psoríase (mediana $=15,5)$, vitiligo (mediana $=13)$, dermatite atópica $($ mediana $=12)$, acne $($ mediana $=10)$. Com respeito aos fatores associados à qualidade de vida, identificou-se que pacientes mais jovens, com menor renda, solteiros, com uma dermatose e com um tempo maior de evolução da doença, apresentam pior qualidade de vida.

Conclusão: A avaliação do impacto na qualidade de vida em pacientes com dermatoses é importante para o manejo clínico. É essencial a detecção daqueles pacientes com maior risco de apresentar uma qualidade de vida pior, para poder abordá-los de uma forma mais integrada.

Palavras-chave: Dermatologia; Epidemiologia; Qualidade de vida

Received on 22.10.2010.

Approved by the Advisory Board and accepted for publication on 21.12.10.

* Work conducted at the outpatient clinic of Hospital Universitário Miguel Riet Correa Júnior - Federal University of Rio Grande (Universidade Federal do Rio Grande) - HU - FURG - Rio Grande do Sul (RS), Brazil.

Conflito de interesse: Nenhum / Conflict of interest: None

Suporte financeiro: Nenhum / Financial funding: None

Dermatologist - M.Sc. student, Federal University of Rio Grande (Universidade Federal do Rio Grande - FURG) - Rio Grande do Sul (RS), Brazil.

Ph.D. in Epidemiology - Professor of the M.Sc. program in Health Sciences, Federal University of Rio Grande (Universidade Federal do Rio Grande - FURG) Rio Grande do Sul (RS), Brazil.

Faculty member - Preceptor at the Dermatology Service, Complexo Hospitalar Santa Casa de Porto Alegre - Professor of Dermatology, Universidade Católica de Pelotas (UCPEL) and Federal University of Pelotas (Universidade Federal de Pelotas - UFPel) - Pelotas (RS), Brazil.

Dermatologist - Professor of dermatology, Federal University of Rio Grande (Universidade Federal do Rio Grande - FURG) - Rio Grande do Sul (RS), Brazil. General Surgeon - Resident Physician of Plastic Surgery, Instituto Ivo Pitanguy - Botafogo (RJ), Brazil. 


\section{INTRODUCTION}

In the last ten years, there has been an increasing interest in assessing the quality of life of patients with skin diseases as well as in the development of methods of assessment. ${ }^{1.4}$

Patients with skin diseases may have their lives affected in many ways. Skin diseases are major causes of morbidity due to the presence of physical symptoms. This was demonstrated in a study where more than $50 \%$ of the patients reported itching and discomfort and $25 \%$ presented severe symptoms.${ }^{5,6}$ It was also demonstrated that skin diseases can cause anxiety, depression, anger and embarrassment, which lead to social isolation and absenteeism at work and school. ${ }^{5}$ Social and sporting activities can become difficult for people with skin conditions due to the fact that they worry about what other people think of their appearance. ${ }^{7}$ Some skin diseases can cause a high degree of disability, comparable to serious chronic diseases. ${ }^{8}$

The treatment of dermatological patients usually focuses on clinical signs and symptoms and on a subjective view of the impact of the disease on the patient's life. Assessing quality of life can help provide patients with better service, by acknowledging their real needs and interfering with treatment decisions.'

The Dermatology Life Quality Index (DLQI) is one of the quality-of-life questionnaires that is specifically designed for skin diseases and can be used both to measure quality of life and to compare it with that found in other cutaneous diseases. ${ }^{7,10}$ This instrument has been used in several studies, both to assess quality of life of dermatological patients in general and in case of specific skin diseases in primary, secondary and tertiary services. ${ }^{11,12}$

Hardly any studies in Brazil have assessed quality of life in patients with skin diseases receiving treatment at SUS's (the Brazilian national public health system) outpatient wards, and most studies are aimed at characterizing the most prevalent causes. Because quality of life is a very important aspect in health, this study aims to examine the quality of life of patients with skin diseases, the main diagnoses found in SUS patients, how much these diseases affect quality of life and what factors may be associated with a worse quality of life.

\section{MATERIALS AND METHODS}

A cross-sectional study was carried out with patients attending the outpatient ward of the Dermatology Department at the University Hospital of the Federal University of Rio Grande do Sul from November 2008 to May 2009. All patients were receiving SUS care and had been referred either from the basic healthcare system or from other public outpatient wards. The sample consisted of patients with a dermatological complaint who were at least 18 years old and who were having their first consultation.

In order to estimate the sample size for prevalence of the most common skin lesions, a $10 \%$ prevalence was estimated for the main diagnoses, with an accuracy of $1.5 \%$ and a confidence level of $95 \%$, arriving at a sample size of 497 patients. The total sample size came to 548 patients, with an addition of $10 \%$ for possible drop-outs.

To calculate the sample size for quality of life, an expected mean of 5 was estimated, with a confidence level of $95 \%$ and a minimum accuracy of 0.5 . These values led to a total of 385 , which was increased by $10 \%$ for possible drop-outs, resulting in a total of 424 patients. As the total for prevalence of the most common skin lesions was higher, this was the total used in the research.

The sampling was carried out by convenience. Patients were invited to participate in the study during the medical consultation, when they received their diagnosis or treatment for their skin disease. They were informed about the study and asked to sign a consent form. After that, they were asked to answer the questionnaire. Due to time limitations and the small number of patients available, no randomization was carried out. All patients who met the characteristics required for the study were included so that the sample size defined could be reached.

Information was collected using a pre-coded questionnaire on a) socio-demographic data: age, gender, skin color, marital status, education level and per capita family income, ranked in quartiles; b) data collected during the consultation, such as non-specific signs, symptoms, prescriptions given by other doctors, family members, nurses, neighbors or by themselves and the diagnosis.

The diagnosis was obtained by anamnesis, skin examination and complementary tests when necessary and performed by a certified dermatologist.

Quality of life was measured using a specific questionnaire for skin diseases: the Dermatology Life Quality Index (DLQI), which grades quality of life by giving a score to each domain. The domains assessed by the DLQI are the following: a) physical symptoms and feelings (questions 1 and 2), b) daily activities (questions 3 and 4), c) leisure (questions 5 and 6), d) work/school (question 7), e) personal relationships (questions 8 and 9) and f) treatment (question 10). The patients should answer the questions keeping in mind the obstacles faced during the previous week. The scores on the questionnaire range from 0 to 30 . The higher the score is, the poorer the quality of life. Results from 0-1 mean no effect of the disease on the patient's quality of life, scores of 2-5 mean a small 
effect, scores of 6-10 mean a moderate effect, scores of 11-20 correspond to a great effect and scores of 2130 mean a very important effect of the disease on the patient's quality of life. ${ }^{11}$ It was the first questionnaire developed for assessing health-related quality of life which is specific to dermatology. It was developed by Finlay and Khan in 1994 and translated and validated into Portuguese, in Brazil, in 2004 by Buerger, Martins and Arruda. ${ }^{13}$ As required by Finlay and Khan, a specific authorization for its use was obtained by the authors. The questionnaire was applied to each patient during individual interviews carried out by trained interviewers.

To assess the level of agreement between diagnoses, $20 \%$ of the patients were randomly chosen and were examined by another dermatologist, who evaluated the patients independently.

A database was created using the software Epi Info 6.04, and the data from the questionnaires were entered in duplicate by two independent typists. The database was then reassessed to detect errors of amplitude or consistency. Afterwards, the database was transferred into a statistical program (Stata 9.0). ${ }^{14}$

In a first phase, a descriptive analysis of the sample was carried out by calculating the prevalence of the dermatological diagnoses, as well as the prevalence of other independent variables.

As the DLQI had a non-normal distribution, the median was chosen as the measure of central tendency and for the statistical tests used.

The univariate analysis consisted of the study of the difference between DLQI scores of different diseases and according to the patient's gender. Differences between genders for the total DLQI score and for each domain were also analyzed. For both analyses, the medians and their $25^{\text {th }}$ and $75^{\text {th }}$ percentiles were used.

The statistical significance of the differences between these groups was evaluated using the Kruskal Wallis test.

The quantile regression was used to assess the association between the medians of the DLQI and the socio-demographic and clinical data. Initially, a crude analysis was carried out, followed by an adjusted one. For the adjusted analysis, the socio-demographic variables were included first, followed by the clinical ones. A backward regression analysis was carried out, and the exclusion of the variables in each step was subjected to a $\mathrm{p}<0.05$, assessed by the Wald test. ${ }^{15,16}$

For all of the analyses, a value of $\mathrm{p}<0.05$ for $\mathrm{a}$ two-tailed test was pre-fixed as a cutoff point.

The project was approved by the Research Ethics Committee (CEPAS) of the Federal University of Rio Grande do Sul (UFRGS).

\section{RESULTS}

During the study period, all patients referred to the dermatology outpatient ward were invited to participate in the study until the sample was completed. No drop-outs were recorded, and 548 patients participated.

The agreement on the diagnosis, assessed by two independent dermatologists, had a kappa score that ranged from 0.8 to 1 , according to the disease.

For the sample characteristics, the patients' age ranged from 18 to 91 years, with a mean of 43.89 years $(\mathrm{SD}=19.2)$. Most of the patients $(67.7 \%)$ were female, with white skin color (95.1\%), married (60\%) and had a low level of education (29.9\% had received less than 3 years of education). Regarding the monthly income, $27 \%$ had a per capita family monthly income of less than 350 reais and $27.5 \%$ between 450 and 641 reais (Table 1 ).

A total of $97.8 \%$ of the patients had been referred by primary care units in the city, and $95.3 \%$ had no diagnosis at referral.

Only $19 \%$ of the patients had used topical medication in the week prior to consultation, the vast majority of which had been prescribed by a pharmacy clerk.

As regards symptoms in the week prior to consultation, the most common one was itching, which was reported by $62.2 \%$ of the patients.

With regard to number of skin diseases diagnosed at the time of consultation, the vast majority of the patients had only one skin disease and 5.3\% had more than three skin diseases at the time of evaluation.

Concerning disease duration, it was observed that most patients had the disease for less than a year, and $11.6 \%$ had the disease for more than 10 years.

The most common diagnoses are listed in table 1. Among them are superficial mycosis (14.4\%), actinic keratosis $(13.1 \%)$, disorders of pigmentation and melanocytic nevi (10.8\%), acne (9.1\%), contact dermatitis (7.1\%) and psoriasis (6.2\%).

The median and mean DLQI scores were 7 and $7.7(\mathrm{SD}=5.0)$, respectively.

The skin diseases with the highest DLQI scores were psoriasis $($ median $=15.5)$, vitiligo $($ median $=$ $13)$, atopic dermatitis $($ median $=12)$, acne $($ median $=$ 10) and contact dermatitis (median $=8$ ).

Regarding the DLQI scores per gender, it was observed that the skin diseases with the highest impact on quality of life in men were psoriasis (median $=17.5)$, vitiligo $($ median $=11)$, non-cicatricial alopecia (median $=12$ ) and atopic dermatitis (median $=10.5$ ). In women, the skin diseases with the highest DLQI scores were atopic dermatitis (median = $20)$, psoriasis $($ median $=14)$, vitiligo $($ median $=14)$ and urticaria (median $=12$ ). There was a statistically 
TABLE 1: Sample Description - consultation and socio-demographic data

\begin{tabular}{|c|c|c|c|c|c|}
\hline Variable & No. & $\%$ & Variable & No. & $\%$ \\
\hline Gender & & & Medication in previous week & & \\
\hline Male & 177 & 32.3 & No & 444 & 81 \\
\hline Female & 371 & 67.7 & Yes & 104 & 19 \\
\hline Age group & & & Prescribed by & & \\
\hline $18-24$ & 123 & 22.4 & Physician & 58 & 10.6 \\
\hline $25-44$ & 153 & 27.9 & Nurse & 13 & 2.4 \\
\hline $45-64$ & 185 & 33.7 & Family member & 6 & 1.1 \\
\hline 65-max. & 87 & 15.8 & Neighbor & 15 & 2.7 \\
\hline Color & & & By themselves & 12 & 2.2 \\
\hline White & 521 & 95.1 & Pharmacist & 444 & 81 \\
\hline Black & 27 & 4.9 & Symptom during previous week & & \\
\hline Marital status & & & No & 115 & 21 \\
\hline Single & 139 & 25.4 & Yes & 433 & 79 \\
\hline Married/w/partner & 326 & 59.5 & Itching & & \\
\hline Separated/divorced & 13 & 2.4 & No & 207 & 37.8 \\
\hline Widowed & 70 & 12.8 & Yes & 341 & 62.2 \\
\hline Education & & & Pain & & \\
\hline Up to 3 years & 164 & 29.9 & No & 382 & 69.7 \\
\hline $4-7$ years & 243 & 44.3 & Yes & 166 & 30.3 \\
\hline 8 years & 101 & 18.4 & Duration & & \\
\hline 9 years or more & 40 & 7.3 & Less than 1 year & 132 & 24.09 \\
\hline Income & & & $1-2$ years & 93 & 16.97 \\
\hline $\mathrm{Up}$ to 350 & 148 & 27 & $2-3$ years & 90 & 16.42 \\
\hline $351-450$ & 113 & 20.6 & 3-4-years & 57 & 10.40 \\
\hline $451-640$ & 151 & 27.5 & $4-5$ years & 57 & 10.40 \\
\hline 641-max. & 136 & 24.8 & $5-10$ years & 55 & 10.04 \\
\hline Referred by & & & More than 10 years & 64 & 11.68 \\
\hline Primary health care service & 535 & 97.8 & Dermatosis & & \\
\hline Hospital outpatient wards & 11 & 2.2 & 1 dermatosis & 442 & 80.66 \\
\hline Diagnosis at referral & & & 2 dermatoses & 77 & 14.05 \\
\hline No & 522 & 95,3 & 3 dermatoses or more & 29 & 5.29 \\
\hline Yes & 26 & 4,7 & & & \\
\hline
\end{tabular}

significant difference in median DLQI scores for pigmentation disorders $(p=0.005)$ and atopic dermatitis $(\mathrm{p}=0.04)$ when men were compared to women. Androgenetic and non-cicatricial alopecia had a borderline difference between genders $(\mathrm{p}=0.06)$.

The domains with the greatest impact on the patients' quality of life were physical symptoms and feelings (Table 2). Women had higher scores in leisure, and men in work/school.

Treatment was the domain that least affected the patients' quality of life in this sample (median $=0$ ).

In the analysis of factors associated with quality of life, age $(p=0.001)$ and marital status $(p=0.005)$ were significant in terms of influencing the outcome variable, as shown in table 3 . The older the patient was, the lower the impact on quality of life; and the youngest patients had the most impaired quality of life due to the presence of skin diseases. Regarding marital status, single patients had a worse quality of life when compared to married, divorced and widowed patients.

Age, income, marital status, education, number of skin conditions and disease duration were the factors that influenced quality of life, after the final adjustment in the multivariate analysis (Table 4). There was a reduction in DLQI scores with age, which shows a linear trend in this variable with adjusted median scores ranging from -0.5 to -2.5 . With respect to income, the second and third quartiles had a better DLQI than the first quartile, and the fourth had the lowest value, showing that patients with higher income have a better quality of life.

Single patients had a worse quality of life than married or widowed patients. The analysis showed that patients with a higher level of education had a worse quality of life. For clinical variables, disease duration exceeding five years negatively affected the quality of life. Patients with just one dermatosis had a 
TABLE 2: Distribution of diagnoses and median DLQI according to gender. Dermatology outpatient ward. University Hospital. Rio Grande do Sul. 2008

\begin{tabular}{|c|c|c|c|c|c|c|}
\hline Variable & $\mathbf{N}$ & $\%$ & $\begin{array}{l}\text { DLQI } \\
\text { (median; p25-p75) }\end{array}$ & $\begin{array}{l}\text { DLQI Men } \\
\text { (median; p25-p75) }\end{array}$ & $\begin{array}{l}\text { Women DLQI } \\
\text { (median; p25-p75) }\end{array}$ & $\mathbf{P}^{\mathbf{b}}$ \\
\hline Superficial Mycosis & 90 & $14.4 \%$ & $7(6-9)$ & $7(6-10)$ & $7(6 ; 8)$ & 0.7 \\
\hline Actinic Keratosis & 72 & $13.1 \%$ & $4(2 ; 7)$ & $4(2 ; 8)$ & $4(2 ; 7)$ & 0.8 \\
\hline Pigmentation Disorders & 59 & $10.8 \%$ & $7(4 ; 9)$ & $2(0 ; 5)$ & $7(5 ; 9)$ & 0.006 \\
\hline Melanocytic nevi & 59 & $10.8 \%$ & $4(1 ; 6)$ & $4(2 ; 6.5)$ & $4(1 ; 6)$ & 0.7 \\
\hline Acne & 50 & $9.1 \%$ & $10(7 ; 13)$ & $10(6 ; 13)$ & $10(8 ; 13)$ & 0.4 \\
\hline Contact Dermatitis & 39 & $7.1 \%$ & $8(6 ; 12)$ & $9.5(7 ; 11.5)$ & $7(5 ; 13)$ & 0.2 \\
\hline Psoriasis & 34 & $6.2 \%$ & $15.5(11 ; 18)$ & $17.5(10 ; 19)$ & $14(11.5 ; 17)$ & 0.3 \\
\hline Seborrheic Keratosis & 30 & $5.5 \%$ & $4(2 ; 6)$ & $5(3 ; 6)$ & $4(2 ; 5)$ & 0.4 \\
\hline Seborrheic Dermatitis & 29 & $5.3 \%$ & $8(4 ; 10)$ & $4.5(2.5 ; 8.5)$ & $8(4 ; 10)$ & 0.5 \\
\hline Diseases of the nails & 22 & $4 \%$ & $8(4 ; 11)$ & $6.5(4.5 ; 8.5)$ & $8(4 ; 11)$ & 0.7 \\
\hline Basal Cell Carcinoma & 17 & $3.1 \%$ & $3(2 ; 7)$ & $3(3 ; 3)$ & $5(2 ; 7.5)$ & 0.5 \\
\hline Vitiligo & 16 & $2.9 \%$ & $13(9 ; 15.5)$ & $11(9 ; 12)$ & $14(9 ; 16)$ & 0.4 \\
\hline $\begin{array}{l}\text { Squamous cell } \\
\text { carcinoma }\end{array}$ & 15 & $2.7 \%$ & $3(2 ; 7)$ & $3(3 ; 3)$ & $4.5(2 ; 7)$ & 0.3 \\
\hline $\begin{array}{l}\text { Non-cicatricial alopecia / } \\
\text { telogen effluvium }\end{array}$ & 15 & $2.7 \%$ & $9(7 ; 10)$ & $12(12 ; 12)$ & $8.5(7 ; 10)$ & 0.06 \\
\hline Urticaria & 13 & $2.4 \%$ & $8(7 ; 14)$ & $5(2 ; 8)$ & $12(8 ; 15)$ & 0.08 \\
\hline $\begin{array}{l}\text { Other follicular } \\
\text { conditions / } \\
\text { Folliculitis }\end{array}$ & 11 & $2 \%$ & $3(1 ; 5)$ & $2(1 ; 5)$ & $4.5(2 ; 6.5)$ & 0.2 \\
\hline Warts & 9 & $1.6 \%$ & $8(4 ; 11)$ & $9.5(7 ; 18)$ & $4(2 ; 8)$ & 0.11 \\
\hline Atopic Dermatitis & 8 & $1.5 \%$ & $12(7.5 ; 17.5)$ & $10.5(6 ; 12)$ & $20(19 ; 21)$ & 0.04 \\
\hline $\begin{array}{l}\text { Follicular cysts of } \\
\text { the skin and } \\
\text { subcutaneous tissue }\end{array}$ & 8 & $1.5 \%$ & $4.5(4 ; 5)$ & $5(4 ; 5)$ & $4(0 ; 5)$ & 0.2 \\
\hline $\begin{array}{l}\text { Lichen simplex } \\
\text { chronicus and prurigo }\end{array}$ & 8 & $1.5 \%$ & $6(3.5 ; 7)$ & $6(2 ; 12)$ & $6(5 ; 7)$ & 0.9 \\
\hline Lupus Erythematosus & 7 & $1.3 \%$ & $1.3 \%$ & $4(4 ; 4)$ & $6(4 ; 6)$ & 0.4 \\
\hline Scabies & 7 & $1.3 \%$ & $8(7 ; 13)$ & $8(7 ; 13)$ & $7(6.5 ; 10)$ & 0.1 \\
\hline Androgenetic Alopecia & 6 & $1.1 \%$ & $6(3 ; 9)$ & $2.5(2 ; 3)$ & $9.5(8 ; 10)$ & 0.06 \\
\hline Alopecia Areata & 4 & $1.1 \%$ & $9(7.5 ; 12.5)$ & $9(6 ; 16)$ & $9(9 ; 9)$ & 1 \\
\hline $\begin{array}{l}\text { Skin and subcutaneous } \\
\text { tissue conditions / } \\
\text { ulcer and factitious } \\
\text { dermatitis }\end{array}$ & 2 & 2 & $9(8 ; 10)$ & $8(8 ; 8)$ & $10(10 ; 10)$ & 0.3 \\
\hline Total & $630^{a}$ & $100 \%$ & $7(4 ; 10)$ & $7(4 ; 10)$ & $7(4 ; 10)$ & 0.7 \\
\hline
\end{tabular}

${ }^{\text {a }}$ More than one diagnosis per patient

${ }^{\mathrm{b}}$ Kruskal-Wallis

DLQI score greater than those with more than one skin problem.

\section{DISCUSSION}

This study demonstrated that quality of life can be affected by skin diseases, especially in domains such as physical symptoms and feelings, social/leisure and work. The overall DLQI score (median $=7$ ) obtained in this study was similar to that obtained in other studies carried out in several countries, which ranged from 6.5 to $7.8 .^{1,11,17-21}$ As the distribution of the DLQI was asymmetric with left skewness, the mean tended to be higher than the median. The overall mean DLQI score was 7.7.

The diseases that this study identified as having the most impact on quality of life are in agreement with the results of other studies carried out in several countries. Psoriasis, vitiligo, atopic dermatitis, acne and contact dermatitis have been the skin diseases with the highest DLQI scores and, therefore, the most relevant regarding the resulting damage. ${ }^{12,22-26}$ Among these, psoriasis has the highest impact. ${ }^{26}$ Other authors have also found that acne and contact dermatitis have the most negative impact. ${ }^{12,18-22}$ According to Â-ztürkcan et al., acne possibly leads to the highest scores because of its potential to cause psychological 
TABLE 3: Scores for domains of DLQI

\begin{tabular}{llllll}
\hline Variable & Mean (SD) & $\begin{array}{l}\text { Median } \\
(\mathrm{P} 25 ; \mathrm{P} 75)\end{array}$ & $\begin{array}{l}\text { Men Median } \\
(\mathrm{P} 25 ; \mathrm{P} 75)\end{array}$ & $\begin{array}{l}\text { Women Median } \\
(\mathrm{P} 25 ; \mathrm{P} 75)\end{array}$ \\
\hline $\begin{array}{l}\text { Physical symptoms } \\
\text { and feelings }\end{array}$ & $2.9(1.4)$ & $3(2 ; 4)$ & $3(2 ; 4)$ & $3(2 ; 4)$ & 0.9 \\
$\begin{array}{l}\text { Daily Activities } \\
\text { Leisure }\end{array}$ & $0.7(1.2)$ & $0(0 ; 1)$ & $0(0 ; 1)$ & $0(0 ; 1)$ & 0.20 \\
$\begin{array}{l}\text { Work / School } \\
\text { Personal Relationships }\end{array}$ & $0.95(0.97)$ & $1(0 ; 2)$ & $0(0 ; 2)$ & $1(0 ; 2)$ & 0.002 \\
Treatment & $0.6(0.8)$ & $0(0 ; 1)$ & $1(0 ; 2)$ & $0(0 ; 1)$ & 0.001 \\
Total & $0.07(0.30)$ & $0(0 ; 0)$ & $0(0 ; 0)$ & $0(0 ; 0)$ & 1 \\
\hline
\end{tabular}

stress and permanent scarring. ${ }^{18}$ Contact dermatitis can cause discomfort and hinder performance of tasks at work due to itching and pain. ${ }^{22}$

Regarding gender, no difference was found between total DLQI scores for men and women. However, when results were compared according to specific skin diseases, there was a statistical difference for pigmentation disorders, which may reflect the greater concern that women have with aesthetics. For acne, men had a higher score. ${ }^{12}$ As for contact dermatitis, there was no difference between genders. ${ }^{22}$ For atopic dermatitis, a U.S. study found that patients had DLQI scores similar to those of other chronic skin diseases. $^{24}$

Regarding the DLQI domains, quality of life can be affected by skin diseases, especially concerning the domains of physical symptoms and feelings, social/leisure and work. Authors found similar results, regardless of the type of skin disease. A study on the impact of psoriasis on quality of life found that the most affected domains were leisure and daily activities. ${ }^{26}$ Other authors showed that with psoriasis, physical activity and personal relationships were negatively impacted in more than $50 \%$ of the cases. ${ }^{27}$ Moreover, this condition had a great impact on the domains of social/leisure for both genders equally, but men were more concerned when it came to the work domain. ${ }^{26}$ Another study conducted in Turkey found that the most affected domains were physical symptoms and feelings and daily activities. ${ }^{18}$ In a study conducted in Belgium, the most important domains for vitiligo patients were physical symptoms and feelings, daily activities and leisure. ${ }^{25}$ It can be seen that the affected domains often coincide, regardless of whether the DLQI was measured for all causes or only for certain diseases.

Regarding the differences between the domains of the DLQI and gender, a statistically significant difference was found for leisure and work/school, with a median that was higher for women in leisure and for men in work/school. These differences may reflect gender social roles, since men were more concerned with skin conditions that affected their job performance while women were affected by changes in appearance at the time of exposure, especially during leisure activities. A study that was carried out on people with acne also found that the most affected domain for women was leisure. ${ }^{12}$ However, when the disease in question was seborrheic dermatitis, the domains most affected for women were physical symptoms and feelings and daily activities. Unlike our present study, they also found higher scores for the treatment domain. ${ }^{28}$ The same study found a statistically significant difference between men and women with acne for the domain of leisure, and higher mean scores for men in the domains of physical symptoms and feelings, daily activities, personal relationships and treatment. ${ }^{12}$

With regard to factors associated with quality of life, this study found the worst scores for patients who were younger, with lower income, single, with one skin condition and longer disease duration. A study by Szepietowski et al. confirms some of our findings. They observed that the quality of life of patients with seborrheic dermatitis was lower for younger female patients, aged from 18 to 24 years, with a lower income and higher education level. One explanation for this association may be the fact that younger patients with more education are more socially active, have more contact with others and greater concern with their physical appearance. ${ }^{28}$ As regards income and quality of life, our findings are confirmed by other studies and show that as income increases, so does the quality of life of patients with skin diseases. ${ }^{28,29}$ Those with fewer resources must find it more difficult to seek medical attention and to initiate and continue treatment, which worsens the skin condition and leads to an inferior quality of life. 
TABLE 4: Raw and adjusted median scores and respective 95\% CI for the index of quality of life in patients with skin diseases. Regression for medians. Rio Grande, 2008

\begin{tabular}{|c|c|c|c|c|}
\hline Variable $^{a}$ & Raw coefficient (IC95\%) & $\mathbf{p}$ & Adjusted Coefficient (IC95\%) & $\mathbf{p}$ \\
\hline \multicolumn{5}{|l|}{ Age $(\text { years })^{\mathrm{df}}$} \\
\hline $25-44$ & $-1.0(-3.9 ; 1.9)$ & $0.000 \mathrm{~b}$ & $-0.5(-2.7 ; 1.7)$ & $0.000 \mathrm{~b}$ \\
\hline $45-64$ & $-3.0(-5.8 ;-0.2)$ & & $-2.0(-4.3 ; 0.3)$ & \\
\hline 64 or more & $-5.0(-8.3 ;-1.7)$ & & $-2.5(-5.4 ; 0.4)$ & \\
\hline \multicolumn{5}{|l|}{ Skin color ${ }^{\mathrm{d}}$} \\
\hline Black & $-1.0(-5.3 ; 3.3)$ & 0.6 & $-1.0(-6.6 ; 4.6)$ & 0.7 \\
\hline \multicolumn{5}{|l|}{ Gender $^{\mathrm{d}}$} \\
\hline Female & $0.0(-2.1 ; 2.1)$ & 1.0 & $0.3(-0.5 ; 1.0)$ & 0.4 \\
\hline \multicolumn{5}{|l|}{ Marital Status ${ }^{\mathrm{d}}$} \\
\hline Married & $-2.0(-4.4 ; 0.4)$ & $0.001 \mathrm{c}$ & $-0.5(-2.6 ; 1.6)$ & $0.02 \mathrm{c}$ \\
\hline Separated & $-2.0(-8.7 ; 4.7)$ & & $0.0(-4.2 ; 4.2)$ & \\
\hline Widowed & $-5.0(-8.4 ;-1.6)$ & & $-2.5(-5.5 ; 0.5)$ & \\
\hline \multicolumn{5}{|l|}{ Education $^{\mathrm{df}}$} \\
\hline $\begin{array}{l}4 \text { to } 7 \text { years } \\
8\end{array}$ & \multicolumn{3}{|c|}{8} & $0.0001 \mathrm{c}$ \\
\hline or more years & $2.0(-0.7 ; 4.7)$ & & $0.6(-0.3 ; 1.5)$ & \\
\hline \multicolumn{5}{|l|}{ Income in reais ${ }^{\mathrm{df}}$} \\
\hline $351-450$ & $-1.0(-4.0 ; 2.0)$ & 1.0 & $-0.5(-2.2 ; 1.2)$ & 0.03 \\
\hline $451-640$ & $-1.0(-3.8 ; 1.8)$ & & $-0.5(-2.1 ; 1.1)$ & \\
\hline 641 or more & $-2.0(-4.8 ; 0.8)$ & & $-1.5(-3.2 ; 0.2)$ & \\
\hline \multicolumn{5}{|l|}{$\begin{array}{l}\text { Number of skin } \\
\text { diseasese }^{f}\end{array}$} \\
\hline 1 dermatosis & 0.0 & & 0.0 & \\
\hline 2 dermatoses or more & $-1.0(-3.4 ; 1.4)$ & 0.4 & $-1.0(-1.5 ;-0.5)$ & 0.000 \\
\hline \multicolumn{5}{|l|}{$\begin{array}{l}\text { Disease duration } \\
\text { (years) }{ }^{\text {ef }}\end{array}$} \\
\hline 5 or more years & $1.0(-1.4 ; 3.4)$ & & $2.0(1.6 ; 2.4)$ & 0.000 \\
\hline $\begin{array}{ll}\text { aase categories: age } 18 \\
3 \text { years, income <350; } \\
\text { b } \\
\text { Test for linear trend } \\
\text { d } & \text { Heterogeneity } \\
\text { ' } & \text { First level Analysis } \\
\text { f } & \text { Second Level Analysis } \\
& \text { Final Model }\end{array}$ & $\begin{array}{l}\text { 4, white skinned, male gender, } \\
\text { dermatosis; less than } 5 \text { years o }\end{array}$ & $\begin{array}{l}\text { arital statı } \\
\text { isease. }\end{array}$ & e; education up to & \\
\hline
\end{tabular}

It was not possible to find other articles that addressed the relationship between quality of life and number of skin diseases. At first glance, our finding seems paradoxical, but it may be due to the fact that when patients have just one skin disease (vitiligo or psoriasis, for example), it tends to be more noteworthy, leading to neglect of other lesions, whereas in cases with two or more skin diseases, the milder pathology prevails.
The study was carried out on patients referred to a SUS dermatology outpatient clinic at a university hospital in southern Brazil. This limits the external validity of this research, as its findings cannot be extended to all individuals with skin lesions. However, given the difficulty of implementing population-based studies with the diagnostic scope and accuracy of this article, our findings enable us to establish some important considerations in terms of the impact that a 
disease has on the quality of life of patients with this type of health condition. The measure of central tendency that we chose (median) was not used in other studies that we reviewed. However, from a methodological point of view, when one considers that the DLQI is a numerical variable ranging from 0 to 30 which may have a skewed distribution, this measure is more appropriate than the mean. In any case, the scores were similar to those of other studies and did not make comparisons difficult, as shown by the overall DLQI score.

Another possible limitation is the inclusion of patients with more than one skin disease. As this was not possible, we decided to include in the model a variable representing the number of skin diseases.

Finally, this study highlights the most frequently found diagnoses in a SUS dermatology outpatient clinic and the importance that skin diseases have in the domains of a patient's quality of life. Patients who are younger, single, and who have longer disease duration tend to have the most negatively impacted quality of life, and these aspects should be taken into account.

The assessment of the impact on the quality of life of patients with skin diseases is important for clinical management. It is essential to detect those patients who are most at risk from being negatively impacted in order to treat them in a more integrated manner, including the decision of whether to use a medication that might have important side effects or not and psychological support for the most severe cases.

Future studies in this research area could assess the quality of life before and after treatment, particularly in cases of chronic diseases that have a greater impact on quality of life.

\section{CONCLUSION}

The assessment of the impact on quality of life in patients with skin diseases is important for clinical management. It is essential to detect patients at a higher risk of experiencing worse quality of life in order to treat them in a more integrated way. 


\section{REFERENCES}

1. Finlay AY, Khan G. Dermatology Life Quality Index (DLQI): A simple practical measure for routine clinical use. Clin Exp Dermatol. 1994;19:210-6.

2. Elewski BE. The effect of toenail onychomycosis on patient quality of life. Int $J$ Dermatol. 1997;36:754-6.

3. Lindholm C, Bjellerup M, Christensen OB, Zederfeldt B. Quality of life in chronic leg ulcer patients. An assessment according to the Nottingham Health Profile. Acta Derm Venereol. 1993:73:440-3.

4. Chren MM, Lasek RJ, Quinn LM, Mostow EN, Zyzanski SJ. Skindex, a quality of life measure for patients with skin disease: Reliability, validity and responsiveness. J Invest Dermatol. 1996;107:707-13.

5. Verhoeven EW, Kraaimaat FW, van de Kerkhof PC, van Weel C, Duller P, van der Valk $P G$, et al. Prevalence of physical symptoms of itch, pain and fatigue in patients with skin diseases in general practice. Br J Dermatol. 2007;156:1346-9.

6. Aktan S, Ozmen E, Sanli B. Anxiety, depression and nature of acne vulgaris in adolescents. Int J Dermatol. 2000;39:354-7.

7. Finlay AY. Quality of life indices. Indian J Dermatol Venerol Leprol. 2004;70:143-6.

8. Walker SL, Shah M, Hubbard VG, Pradhan HM, Ghimire M. Skin disease is common in rural Nepal: results of a point prevalence study. Br J Dermatol. 2008;158:334-8.

9. David SE, Ahmed Z, Salek MS, Finlay AY. Does enough quality of life-related discussion occur during dermatology outpatient consultations? $\mathrm{Br} J$ Dermatol. 2005; 153:997-1000.

10. Basra MK, Fenech R, Gatt RM, Salek MS, Finlay AY. The Dermatology Life Quality Index 1994 - 2007: a comprehensive review of validation data and clinical results. $\mathrm{Br}$ J Dermatol. 2008;159:997-1035.

11. Harlow D, Poyner T, Finlay AY, Dykes PJ. Impared quality of life of adults with skin disease in primary care. Br J Dermatol. 2000;143: 979-982.

12. Abdel-Hafez K, Mahran AM, Hofny ER, Mohammed KA, Darweesh AM, Aal AA. The impact of acne vulgaris on the quality of life and psychologic status in patients from upper Egypt. Int J Dermatol. 2009;48:280-5.

13. Lewis V, Finlay AY. 20 years experience of the psoriases disability index (PDI). Br J Dermatol. 2004;151(Suppl 68):50-1.

14. Oztürkcan S, Ermertcan AT, Eser E, Sahin MT. Cross validation of the Turkish version of dermatology life quality index. Int J Dermatol. 2006;45:1300-7.

15. Zachariae R, Zachariae C, Ibsen H, Mortensen JT, Wulf HC. Dermatology Life Quality Index: Data from Danish inpatients and outpatients. Acta Derm Venereol. 2000;80:272-6.

16. Hahn HB, Melfi CA, Chuang TY, Lewis CW, Gonin R, Hanna MP, et al. Use of the Dermatology Life Quality Index (DLQI) in a midwestern US urban clinic. J Am Acad Dermatol.. 2001;45: 44-8.

17. Badia X, Mascaró JM, Lozano R. Measuring health-related quality of life in patients with mild to moderate eczema and psoriasis: clinical validity, reliability and sensitivity to change of the DLQI. Br J Dermatol. 1999;141:698-702.
18. Hutchings CV, Wan Shum K, Gawkrodger DJ. Occupational contact dermatitis has an appreciable impact on quality of life. Contact Dermatitis. 2001;45:17-20.

19. Linnet J, Jemec GBE. An assessment of anxiety and dermatology life quality in patients with atopic dermatitis. B J Dermatol. 1999;140:268-72.

20. Kiebert G, Sorensen SV, Revicki D, Fagan SC, Doyle JJ, Cohen J, et al. Atopic dermatitis is associated with a decrement in health-related quality of life. Int J Dermatol. 2002; $41: 151-8$.

21. Ongenae K, Van Geel N, De Schepper S, Naeyaert JM. Effect of vitiligo on self-reported health-related quality of life. Br J Dermatol. 2005;152:1165-72.

22. Gupta MA, Gupta AK. Age and gender differences in the impact of psoriasis on quality of life. Int J Dermatol. 1995;34:700-3.

23. AL-Mazeedi K,El-Shazly M, Al-Ajmi HS. Impact of psoriasis on quality of life in Kuwait. Int J Dermatol. 2006;45:418-24.

24. Szepietowski JC, Reich A, Wesołowska-Szepietowska E, Baran E; for the National Quality of Life in Dermatology Group. Quality of life in patients suffering from seborrheic dermatitis: influence of age, gender and education level. Mycoses. 2008;52: 357-63.

25. Ongenae K, Van Geel N, De Schepper S, Naeyaert JM. Effect of vitiligo on self-reported health-related quality of life. Br J Dermatol. 2005;152:1165-72.

26. Gupta MA, Gupta AK. Age and gender differences in the impact of psoriasis on quality of life. Int J Dermatol. 1995; 34: 700-3

27. AL-Mazeedi K,EI-Shazly M, Al-Ajmi HS. Impact of psoriasis on quality of life in Kuwait. Int J Dermatol. 2006;45:418-24.

28. Szepietowski JC, Reich A, Wesołowska-Szepietowska E, Baran E; for the National Quality of Life in Dermatology Group. Quality of life in patients suffering from seborrheic dermatitis: influence of age, gender and education level. Mycoses. 2008;52:357-63.

29. Sociedade Brasileira de Dermatologia: Perfil nosológico das consultas dermatológicas no Brasil. An Bras Dermatol. 2006;81:549-58.

How to cite this article/Como citar este artigo: Tejada CS, Mendoza-Sassi RA, Almeida Junior HL, Figueiredo PN, Tejada VFS. Impact on the quality of life of dermatological patients in southern Brazil. An Bras Dermatol. 2011;86(6):1113-21. 